\title{
Analysis of Local Government Financial Information Quality Based on Internal and External Factors
}

\author{
I Gusti Ayu Purnamawati ${ }^{1, a^{*}}$, Saarce Elsye Hatane ${ }^{2, b}$ \\ ${ }^{1}$ Economic and Accounting Department, Faculty of Economic, Universitas Pendidikan Ganesha \\ Jalan Udayana No 11 C, Singaraja, Bali \\ 2 Accounting Department, Faculty of Economic and Business, Petra Christian University \\ Jl. Siwalankerto No.121-131, Siwalankerto, Surabaya \\ e-mail: ${ }^{a}$ igapurnamawati@gmail.com, ${ }^{b}$ elsyehat@petra.ac.id \\ * Corresponding Author
}

\begin{abstract}
This study attempts to analyze the quality of local government financial information through internal and external factors. This type of research is a causative research using primary data collected through a questionnaire using a likert scale of 1-5. The location of this research is in Buleleng Regency, Bali Province. The sample of this study consisted of the head of the finance department and the accounting staff at each Regional Work Units, amounting to 45 people. The analytical method used in this research is multiple linear regression. The results showed that the competency and working experience (as internal factors), implementation of accounting information system, the role of internal audit (as external factors) had a positive and significant effect on the quality of local government financial reports However, in the future it is hoped that it can be improved through improvements and guidance in several aspects such as increasing the capacity of government officials regarding a more adequate regional financial accounting information system through improving facilities and infrastructure to support regional financial management to achieve good, transparent and accountable governance.
\end{abstract}

Keywords: financial reports quality, local government, internal audit

Article History: Received: August, 282020 Revised: September, 72020 Accepted: October, 102020

How to cite: Purnamawati, I.G.A., \& Hatane S.E. (2020). Analysis of Local Government Financial Information Quality Based on Internal and External Factors. Akrual: Jurnal Akuntansi, 11(2):66-81. DOI: https://doi.org/10.26740/jaj.v11n2.p66-81.

\section{INTRODUCTION}

The increasing public demand for good governance has encouraged the central and local governments to implement public accountability. The current phenomenon that occurs in the development of the public sector in Indonesia is the strengthening of accountability and demands for transparency of public institutions, both central and regional.

The form of accountability in government administration is regulated in Law Number 17 of 2003 concerning State Finance and Law Number 32 of 2004 concerning Local Government, in the form of Financial Statements. Financial statements as a form of public accountability reflect the comprehensive conditions of operational activities, financial position, cash flow, and disclosure of items in the financial statements. Company characteristics are predictors of the quality of disclosures, statements that can be applied to 
local government. The characteristics of local governments can explain compliance with mandatory disclosure in financial reports, so that the characteristics of local governments are predictors of mandatory disclosure (Agustiningsih et al., 2017). Therefore, the information contained in the Local Government Financial Statements must be useful and in accordance with the needs of the users (Sari, 2014). Huang, et al (2007), information will be useful if an information can support decision making and can be understood by users. The challenge faced by the public sector is providing information that can be used to monitor the accountability of local governments, which consists of financial accountability, managerial accountability, legal accountability, political accountability and policy accountability. The information provided in the financial statements must be equipped with appropriate disclosures so that it is understandable and does not lead to misinterpretation. Disclosures are intended to provide information that is considered important in achieving financial reporting objectives and to serve various parties who have different interests (Suwardjono, 2011).

The quality of financial reports can be seen from the qualitative characteristics of financial reports. According to Government Regulation Number 71 of 2010, the qualitative characteristics of government financial reports which are normative prerequisites as stated in the Government Accounting Conceptual Framework include: Relevant, if the information has benefits, under the actions performed by users of financial statements. Reliable, meaning that the information in the financial statements is free from misleading ideas and material errors, presents every fact honestly, and can be verified. Comparable, this means that the information contained in the financial statements will be more useful when compared to the financial statements of the previous period. Understandable, meaning that the information presented in the financial statements can be understood by users and expressed in terms and terms that are adjusted to the user's understanding limits. Understanding the importance of the quality of financial reports is one form of implementing policies that have been made and can be used as a measure in increasing individual competence. According to Yuliani, et al (2010), the low quality of financial reports can be caused by understanding the accounting from the compilers of the financial statements themselves. Local governments that do not meet the qualitative characteristics of government financial statements as required by Government Regulation No. 71/2010 will result in regional losses, potential regional losses, lack of revenue, administrative weaknesses, inefficiency, and ineffectiveness (Fitriana \& Wahyudin, 2017).

According to the structure of the Local Government, what is meant by the head of the entity is each Head of Regional Work Units as an accounting entity and each regent as a reporting entity. Regional Work Units is an accounting entity that has the obligation to record transactions of income, expenditure, assets and other than cash that occur within the Regional Work Units. In the government sector, each section must be filled in by the right person, who has a predetermined main function. In addition to understanding accounting, the use of information technology can also improve the quality of local government 
financial reports. To achieve accountability and transparency in regional financial management, the use of information technology is a necessity that must be met in helping the speed, effectiveness and efficiency of data management. In order to implement a fast and accurate information delivery process with the aim of producing good financial reports, the central and local governments are obliged to develop and adapt advances in information technology. Currently, Regional Work Units has utilized information technology that produces an information system, which provides information on regional finances that can be accessed, managed and utilized by various parties and the wider community (Diani, 2014).

In accordance with the Government Regulation of the Republic of Indonesia Number 56 of 2005, the Regional Financial Information System hereinafter abbreviated as SIKD is a system that documents, administers, and processes regional financial management data and other related data into information presented to the public and as material for decision making. This is in the framework of planning, implementing, and reporting the accountability of local governments. The information system applied to local governments is the Regional Work Units Management Information System, which is a computerized accounting information system for local governments (Astuti, 2008). The use of regional financial accounting information systems is very important in creating quality financial reports. Research by Fitriana \& Wahyudin (2017) shows that the use of accounting information systems has a significant positive effect on the quality of local government financial reports. Research conducted by Anggriawan \& Yudianto (2018) shows that the application of Governmental Accounting Standards, the quality of human resources, internal control systems, the use of information technology, organizational commitment, the role of internal auditors, assets, external factors, and management of special school operational funds for the West Bandung Regency Education Office have an effect on the quality of financial reports. The research by Diani (2014) shows that the use of regional financial accounting information systems does not have a significant effect on the quality of financial reports. Research by Sari (2014) shows that there is a positive and significant influence between the use of the Regional Financial Accounting Information System on the quality of financial reports.

Professional work experience plays an important role in improving employee performance, especially in improving the quality of financial reports. The experience of employees working in an organization can increase their ability to do work. Experience is a process of learning and development of potential behavior both from formal and nonformal education or it can be interpreted as a process that leads a person to a higher behavior pattern. Someone's work experience shows the types of work someone has done and provides a great opportunity for someone to do a better job (Zainullah et al., 2012). The longer work experience a person has, the greater the level of skills and knowledge a person has, so that it is hoped that the quality of work will be better and be able to complete the task well, this means that the person has good work effectiveness. Employee 
experience in work will give the employee the ability to describe the main duties and functions and responsibilities contained in the organizational structure and the existing standard operating procedures. Furthermore, the main tasks and functions of existing organizations are described in institutional cooperation with the ability to carry out the institutional tasks themselves. The work experience of financial (accounting) staff will make it easier to do work in their field. Professional work experience in accounting will provide more convenience and accuracy in the process of preparing financial statements. Research conducted by Charolina \& Abdullah (2013) shows that work experience has a positive and significant effect on the quality of financial reports.

The low quality of local government financial reports is also influenced by the role of internal audit, in this case the role of the inspectorate as an internal supervisor in government. The Government Internal Supervisory Apparatus must be able to provide assurance that all accounting and financial reporting processes have been implemented in accordance with Government Accounting Standards to produce quality financial reports. The role of internal audit is to provide advisory services and quality assurance of financial reports, especially to review local government financial reports. One way to see whether the financial statements that have been prepared are in accordance with Government Accounting Standards and in accordance with the expected quality, can be seen from the auditor's opinion.

Based on the findings of the Supreme Audit Agency, there have been cases of accounting and reporting weaknesses consisting of inaccurate records, the process of preparing financial reports that is not in accordance with the provisions of SAP, the entity is late in submitting reports, the accounting information system and reporting are unadequate, and un-supported by adequate human resources (Ratifah \& Ridwan, 2012). It is hoped that the inspectorate as the local government's internal auditor can assist local governments in preparing quality and reliable financial reports. In line with research by Yuliani et al. (2010), Diani (2014), Sari (2014), the research shows that the role of government internal auditors has a significant positive effect on the quality of government financial reports. The higher the application of an effective internal control system can reduce the level of fraud that occurs (Praditasari \& Asrori, 2018).

In addition, based on the results of the audit by the Supreme Audit Agency on the Regional Government Financial Statements for the 2013 fiscal year, of the 10 entities audited by the Supreme Audit Agency, namely the Bali Provincial Government and nine district / city governments. Buleleng Regency Government for Regional Government Financial Report for Fiscal year 2013 received a qualified opinion. The unqualified opinion received by Buleleng Regency was the same as the opinion of the Supreme Audit Agency on the previous year's Regional Government Financial Report. The exception to this reasonableness is caused by several weaknesses, namely the ineffective implementation of the Regional Property assessment activities. The implementation of the Census of Regional Property by the Government of Buleleng Regency in 2013 has not optimal; The 
management and administration of the Buleleng Regency Government's assets are not orderly. The Supreme Audit Agency also found non-compliance with statutory regulations in regional financial management, namely: overpayments of regional official travel expenditures in 11 Regional Government Work Units amounting to IDR 412,674,250.00. There is a summons from the Third Party to the Buleleng Regency Government regarding the Procurement of Goods and Services for the period 2008-2012 amounting to IDR 2,968,318,430.55. The Supreme Audit Agency also found several weaknesses in the Internal Control System and compliance with other laws and regulations, it's just that the weaknesses found are not sufficiently material to be made an exception (bali.bpk.go.id). The results of the audit by the Supreme Audit Agency showed that the regional financial management of the Buleleng Regency Government was quite good.

\section{Competency and Quality of Local Government's Financial Reports}

Financial statement information will correlate with the quality of financial reporting itself if stakeholders view financial reporting not only in terms of formality, but also in terms of its substance. Taking into account the importance of the quality of financial reports is one form of the implementation of the policies that have been made. The quality of financial reports will be good if financial reporting is carried out based on Government Accounting Standards (Charolina \& Abdullah, 2013). Therefore, every part of government must be filled with human resources who have competence in understanding accounting and other related financial sciences. The higher the level of accounting understanding of the head of the financial subdivision and the accounting staff, the better the quality of the financial reports it produces (Diani, 2014). Research conducted by Yuliani et al (2010) states that accounting understanding affects the quality of regional financial reports. Based on the description above, the hypothesis can be formulated:

\section{H1: Competency has a positive and significant effect on the quality of local Government's financial reports}

\section{Implementation of Accounting Information System and Quality of Local Government's Financial Reports}

The existence of an accounting information system network facility that is specifically designed for the preparation of financial reports starting from journal recording, ledgers to financial reports, all have been systemized using a computerized system which will reduce the error rate in calculations and save time in the compilation process. Research conducted by Muda et al (2018) show that the accounting information system affects the quality of local government financial reports. In line with the research by Muda et al (2018), Sari (2014) shows the same thing that there is a positive and significant influence between the use of the Regional Financial Accounting Information System on the quality of financial reports. Based on the description above, the hypothesis can be formulated: 
H2: Implementation of accounting information system has a positive and significant effect on the quality of local Government's financial reports.

\section{Work Experience and Quality of Local Government's Financial Reports}

To be able to meet the normative prerequisites required for government financial reports to meet good quality, employee work experience is required. The longer the work experience, the more experienced an employee is, so it is hoped that the quality of work will be better (Charolina \& Abdullah, 2013). According to Edy (2009), the longer the work experience, the more experienced an employee, so it is hoped that the quality of work will be better. Professional work experience plays an important role in improving employee performance, especially in improving the quality of financial reports. The results of research conducted by Charolina \& Abdullah (2013) show that work experience has a positive and significant effect on the quality of financial statements. Based on the description above, the hypothesis can be formulated:

H3: Work experience has a positive and significant effect on the quality of local Government's financial reports.

\section{The Role of Internal Audit and Quality of Local Government Financial Reports}

The role of the inspectorate greatly affects the quality of financial reports because supervision is an activity of assessing the organization / activity so that the organization carries out its main tasks and functions properly and correctly to achieve the stated objectives. The role of the inspectorate as the government's internal supervisor will be able to assist local governments in preparing quality and reliable government financial reports (Sari, 2014). Research conducted by Diani (2014) shows that the role of internal audit has a significant positive effect on the quality of financial statements. Research by Tambingon (2018) regarding the role of internal audit also shows a significant effect on the quality of local government financial information. Based on the description above, the hypothesis can be formulated:

\section{H4: The role of internal audit has a positive and significant effect on the quality of local Government's financial reports.}

\section{RESEARCH METHOD}

Independent variables in this study are competency, implementation of accounting information systems, work experience, and the role of internal audit while the quality of financial reports is the dependent variable. Methods of data collection using a research instrument in the form of a questionnaire. The collected data is then tested first with validity and reliability tests. The quantitative analysis technique used is multiple linear regression analysis techniques. The data source in this study is primary data obtained by using a structured list of questions in order to collect information from respondents through a questionnaire. 
The population in this study was 45 Regional Work Units of Buleleng Regency consisting of the Regional Secretariat, Council Secretariat, Inspectorate, Regional Development Planning and Investment Board, Regional Offices and Technical Institutions. The sampling technique used was judgment sampling. The judgment sampling technique is a sampling technique based on the researcher's judgment that the best party to be used as a research sample. The sample in this research consists of 45 Regional Work Units. Respondents in this study were the Head of Finance Sub Division / Head of Sub Division of financial administration and accounting staff at each Regional Work Units, so the number of respondents was 45 people from 45 Regional Work Units. The reason for choosing the respondent for the Head of Subdivision of Finance / Head of Subdivision of financial administration because they were responsible for making financial reports at each Regional Work Units and was an important element in producing government financial reports, and directly involved in preparing financial reports and understanding the accounting process. The reason for choosing accounting staff respondents is because these staff use SIADINDA (Local Office Accounting Information System) in preparing financial reports and are directly involved in the process of preparing financial reports and understanding the accounting process. Measurement of variables using a Likert scale with five alternative answers, each given a score as follows: score $5=$ Strongly Agree, score $4=$ Agree, score $3=$ Doubt, score $2=$ Disagree, score $1=$ Strongly Disagree.

Descriptive statistics provide an overview or description of data seen from the mean, standard deviation, variant, maximum, minimum, sum, range, kurtosis and skewness (slope distribution) (Ghozali, 2011). The validity test in this study used Corrected Product Moment. If $r_{\text {count }}>r_{\text {table }}$ and is positive then the question item or indicator is declared valid. The validity test is done by correlating the factor score with the total score. If the correlation of each factor is positive and the amount is $>0.30$ then the item is declared valid but if the correlation value is less than 0.30 then the item is declared invalid (Sugiyono, 2014). The technique used to test the validity is done by using the Pearson product moment correlation coefficient. For two-sided testing of the SPSS 19.0 for Windows software program. A questionnaire is said to be reliable or reliable if someone's answer to a question is constant or stable over time. In this study, the reliability test uses Alpha Cronbach, the value of an instrument is said to be reliable if the Cronbach Alpha value is greater than 0.600 (Sugiyono, 2014). To test the hypothesis in this study, multiple linear regression analysis tools were used to see the effect of several independent variables on the dependent variable which is formulated as follows:

$Y=\alpha+\beta_{1} X_{1}+\beta_{2} X_{2}+\beta_{3} X_{3}+\beta_{4} X_{4}+e$

Information: $\mathrm{Y}=$ Quality of Local Government Financial Report; $\alpha=$ Constant; $\beta$ ${ }_{1,2,3,4}=$ regression coefficient of the independent variable; $\mathrm{e}=$ error term; $\mathrm{X}_{1}=$ Competency; $\mathrm{X}_{2}=$ Implementation of Accounting Information System; $\mathrm{X}_{3}=$ Work Experience; $\mathrm{X}_{4}=$ Role of Internal Audit; the interpretation of the regression results analysis is as follows.

The $t_{\text {test }}$ basically shows how far the influence of the independent variable on the dependent variable by assuming the other independent variables are constant, with the 
assumption that if the value of $t_{\text {count }}>t_{\text {table }}$ with a significance of 0.05 it can be concluded that partially the independent variable has a significant effect on the dependent variable or it can be done by looking at significant value below 0.05 . Conversely, if $t_{\text {count }}<t_{\text {table }}$ with a significant 0.05 , it can be concluded that partially the independent variable has no significant effect on the dependent variable or it can be done by looking at the significance that is above 0.05 (Ghozali, 2011). The small Adjusted R Square value means that the ability of the independent variables to explain the variation in the dependent variable is very limited. A value close to 1 (one) means that the independent variables provide almost all the information needed to predict the variation in the dependent variable (Ghozali, 2011).

\section{RESULTS AND DISCUSSION}

The general description of the research results through the description of the score of competency, implementation of regional financial accounting information system, work experience, the role of internal audit, and the quality of financial reports are presented in Table 1.

Table 1. Description of the Score of Each Variable

\begin{tabular}{lccccc}
\hline \multicolumn{1}{c}{ Statistics } & $\mathrm{X}_{1}$ & $\mathrm{X}_{2}$ & $\mathrm{X}_{3}$ & $\mathrm{X}_{4}$ & $\mathrm{Y}$ \\
\hline Mean & 23,24 & 40,57 & 26,00 & 33,52 & 46,48 \\
Minimum & 19,00 & 37,00 & 23,00 & 28,00 & 43,00 \\
Maximum & 28,00 & 45,00 & 30,00 & 37,00 & 51,00 \\
Standard deviation & 2,33 & 2,24 & 1,87 & 2,30 & 2,12 \\
\hline
\end{tabular}

Source: processed data

Based on Table 1: (1) the average score of the competency variable is close to its minimum value, then on average the accounting understanding variable has almost the same value. (2) On average, the variable score of implementation of accounting information system is close to its minimum value, so on average the variable of the use of the regional financial accounting information system has almost the same value. (3) On average, the work experience variable score is close to the minimum value, so on average the work experience variable has almost the same value. (4) On average, the internal audit role variable score is close to its minimum value, so on average the internal audit role variable has almost the same value. (5) On average, the score for the quality of financial statements is close to its minimum value, so on average, the variable quality of financial statements has almost the same value.

Based on the test results, the number of respondents to the questionnaire was 45 respondents so that the $\mathrm{r}$ table price was 0.291 and the product moment correlation

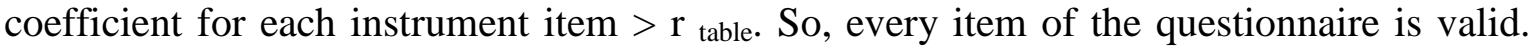
The reliability of the research instrument was assessed by means of the Cronbach Alpha Coefficient, which shows the internal consistency of the items underlying a variable. In summary, the results of the reliability test are presented in Table 2. 
Table 2. Instrument Reliability Test Results

\begin{tabular}{lc}
\hline \multicolumn{1}{c}{ Variable } & $\begin{array}{c}\text { Cronbach's } \\
\text { Alpha } \\
\text { Coefficient }\end{array}$ \\
\hline Competency $\left(\mathrm{X}_{1}\right)$ & $0,759^{*}$ \\
Implementation of Accounting Information Systems $\left(\mathrm{X}_{2}\right)$ & $0,682^{*}$ \\
Work Experience $\left(\mathrm{X}_{3}\right)$ & $0,736^{*}$ \\
The Role of Internal Audit $\left(\mathrm{X}_{4}\right)$ & $0,704^{*}$ \\
Quality of Financial Statements $\left(\mathrm{X}_{5}\right)$ & $0,653^{*}$ \\
\hline
\end{tabular}

Information: *) Reliable (Alpha Cronbach>0.600)

The results of the reliability test in Table 2 show that the instruments of competency, implementation of accounting information systems, work experience, the role of internal audit, and the quality of financial reports are reliable. The data distribution normality test was carried out on all variables. The recapitulation of the data normality test results is presented in Table 3.

Table 3. Recapitulation of Data Normality Test Results

\begin{tabular}{lccc}
\hline & \multicolumn{3}{c}{ Kolmogorov-Smirnov } \\
\cline { 2 - 4 } \multicolumn{1}{c}{ Unit of Analysis } & Statistic & $d f$ & Sig. \\
\hline Competency & 0,128 & 45 & $0,057^{*}$ \\
Implementation of Accounting Information Systems & 0,127 & 45 & $0,059^{*}$ \\
Regional Finance & & & \\
Work Experience & 0,116 & 45 & $0,142^{*}$ \\
The Role of Internal Audit & 0,123 & 45 & $0,077^{*}$ \\
Quality of Financial Statements & 0,127 & 45 & $0,060^{*}$ \\
\hline
\end{tabular}

Note: $\left.{ }^{*}\right)$ data is normally distributed with a significance $>0.05$

Based on Table 3, it shows that the data distribution in all units of analysis is normally distributed. The multicollinearity test can be tested using Variance Inflation Factor (VIF) for each of the independent variables presented in Table 4.

Table 4. Summary of Multicollinearity Test Results

\begin{tabular}{|c|c|c|}
\hline \multirow{2}{*}{ Model } & \multicolumn{2}{|c|}{ Collinearity Statistics } \\
\hline & Tolerance & VIF \\
\hline \multicolumn{3}{|l|}{ (Constant) } \\
\hline Competency & $0,365^{*}$ & $2,740 * *$ \\
\hline Implementation of Accounting Information Systems & $0,270 *$ & $3,698 * *$ \\
\hline Work Experience & $0,187^{*}$ & $5,347 * *$ \\
\hline The Role of Internal Audit & $0,510^{*}$ & $1,959 * *$ \\
\hline
\end{tabular}

Information: *) Non Multicollinearity (tolerance value $>0.1$ )

**) Non Multicollinearity (VIF value < 10)

Based on Table 4, it is known that among the independent variables there is no 
correlation or multicollinearity does not occur in the linear regression model. To test for hiteroscedasticity, the Glejser test can be used. A summary of the results of the heteroscedasticity test is presented in Table 5.

Table 5. Heteroscedasticity Test Results

\begin{tabular}{ccccccc}
\hline \multirow{2}{*}{ Model } & \multicolumn{2}{c}{$\begin{array}{c}\text { Unstandardized } \\
\text { Coefficients }\end{array}$} & $\begin{array}{c}\text { Standardized } \\
\text { Coefficients }\end{array}$ & \multirow{2}{*}{$\mathrm{t}$} & \multirow{2}{*}{ Sig. } \\
\cline { 3 - 5 } & $\mathrm{B}$ & Std. Error & Beta & & \\
\hline 1 & (Constant) & 0,654 & 1,177 & & 0,555 & $0,582^{*}$ \\
& $\mathrm{X}_{1}$ & $-0,019$ & 0,038 & $-0,128$ & $-0,508$ & $0,614^{*}$ \\
& $\mathrm{X}_{2}$ & $-0,039$ & 0,046 & $-0,245$ & $-0,837$ & $0,407^{*}$ \\
& $\mathrm{X}_{3}$ & 0,035 & 0,067 & 0,187 & 0,530 & $0,599^{*}$ \\
& $\mathrm{X}_{4}$ & 0,027 & 0,033 & 0,175 & 0,820 & $0,417^{*}$ \\
\hline
\end{tabular}

Note: *) The significance value between independent variables and absolute residuals > 0.05

Based on Table 5, it can be concluded that there is no heteroscedasticity problem in the regression model. In this study, four hypotheses were proposed. Hypothesis testing uses multiple linear regression analysis. The recapitulation of the results of multiple linear regression analysis is presented in Table 6 , Table 7 and Table 8.

Table 6. Results of Coefficient of Determination Analysis

\begin{tabular}{ccccc}
\hline Model & $\mathrm{R}$ & $\mathrm{R}$ Square & $\begin{array}{c}\text { Adjusted } \mathrm{R} \\
\text { Square }\end{array}$ & $\begin{array}{c}\text { Std. Error of the } \\
\text { Estimate }\end{array}$ \\
\hline 1 & 0,962 & 0,926 & 0,919 & 0,60279 \\
\hline
\end{tabular}

Table 7. Multiple Linear Regression Equation Analysis Results

\begin{tabular}{|c|c|c|c|c|c|c|}
\hline & \multirow[t]{2}{*}{ Model } & \multicolumn{2}{|c|}{$\begin{array}{c}\text { Unstandardized } \\
\text { Coefficients }\end{array}$} & \multirow{2}{*}{$\begin{array}{c}\text { Standardized } \\
\text { Coefficients } \\
\text { Beta }\end{array}$} & \multirow[t]{2}{*}{$\mathrm{t}$} & \multirow[t]{2}{*}{ Sig. } \\
\hline & & $\mathrm{B}$ & Std. Error & & & \\
\hline \multirow[t]{5}{*}{1} & (Constant) & 13,371 & 1,962 & & 6,815 & 0,000 \\
\hline & $\mathrm{X}_{1}$ & 0,172 & 0,064 & 0,189 & 2,689 & 0,010 \\
\hline & $X_{2}$ & 0,301 & 0,077 & 0,318 & 3,897 & 0,000 \\
\hline & $X_{3}$ & 0,478 & 0,111 & 0,423 & 4,309 & 0,000 \\
\hline & $X_{4}$ & 0,134 & 0,055 & 0,145 & 2,444 & 0,019 \\
\hline
\end{tabular}

Table 8. Recapitulation of the Meaningfulness of Multiple Linear Regression Test Results

\begin{tabular}{|c|c|c|c|c|c|c|}
\hline & Model & $\begin{array}{c}\text { Sum of } \\
\text { Squares }\end{array}$ & $\mathrm{df}$ & $\begin{array}{l}\text { Mean } \\
\text { Square }\end{array}$ & $\mathrm{F}$ & Sig. \\
\hline \multirow[t]{3}{*}{1} & Regression & 186,581 & 4 & 46,645 & 128,372 & 0,000 \\
\hline & Residual & 14,898 & 41 & 0,363 & & \\
\hline & Total & 201,478 & 45 & & & \\
\hline
\end{tabular}


Based on Table 6, it is known that the calculation result of the coefficient of determination is 0.919 , namely 91.9 percent of the variable quality of financial statements is influenced by the independent variable, while $8.1 \%$ is influenced by other factors. Based on Table 8 , it is known that the results of the regression calculation $\beta_{1}=0.172, \beta_{2}=0.301, \beta_{3}=$ $0.478, \beta_{4}=0.134$, and $\alpha=13.371$. Thus, the relationship between the variables and the regression equation obtained a positive coefficient direction, which indicates that the variables of competency, implementation of regional financial accounting information systems, work experience, and the role of internal audit have a positive effect on the quality of financial reports. Based on Table 9, the results of the $F_{\text {test }}$ obtained that the value of $F_{\text {count }}$ $=128.372$ with a probability of 0.000 . Because the probability $<0.05$, the regression model can be used to predict the quality of financial statements.

Based on Table 7 , the regression coefficient for competency is 0.172 , the direction of the coefficient is positive which indicates that competency has a positive effect on the quality of financial reports. Based on Table 8 , the tcount $=2.689$ with a significance level of $<0.05$ is obtained. The value of $t_{\text {table }}(2$-tailed $)$ at $d k=45-1=44$ is 2.021 . Because $t_{\text {count }}$ $>\mathrm{t}_{\text {table }}$ and a significance level $<0.05$, it can be concluded that there is a significant influence between competency on the quality of financial reports.

Based on Table 7, the regression coefficient of the implementation of accounting information system is 0.301 , the direction of the coefficient is positive, which indicates that the use of the regional financial information system has a positive effect on the quality of financial reports. Based on Table 8 , it is found that the $t_{\text {count }}$ price is 3,897 with a significance level of $<0.05$. The value of $t_{\text {table }}(2-$ tailed $)$ at $\mathrm{dk}=45-1=44$ is 2.021 . Because $t_{\text {count }}>t_{\text {table }}$ and a significance level $<0.05$, it can be concluded that there is a significant influence between the implementation of financial accounting information systems on the quality of financial reports.

Based on Table 7 , the regression coefficient for work experience is 0.478 , the direction of the coefficient is positive, which indicates that work experience has a positive effect on the quality of financial statements. Based on Table 8 , it is found that the tcount price is 4.309 with a significance level of $<0.05$. The value of $t_{\text {table }}(2-$ tailed $)$ at $d k=45-1=$ 44 is 2.021 . Because $t_{\text {count }}>$ from $t_{\text {table }}$ and a significance level $<0.05$, it can be concluded that there is a significant influence between work experience on the quality of financial statements.

Based on Table 7, the regression coefficient for the role of internal audit is 0.134 , the direction of the coefficient is positive, indicating that the role of internal audit has a positive effect on the quality of financial reports. Based on Table 8 , it is found that the tcount price is 2.444 with a significance level of $<0.05$. The value of $t_{\text {table }}(2$-tailed $)$ at $d k=$ $45-1=44$ is 2.021. Because $t_{\text {count }}>t_{\text {table }}$ and a significance level $<0.05$, it can be concluded that there is a significant influence between the role of internal audit on the quality of financial statements.

\section{The Effect of Competency on the Quality of Local Governments Financial Reports}

The results showed that there was a positive and significant effect between competency and the quality of local governments financial reports. The regression equation has a positive coefficient direction. There is a significant effect of competency on the quality of financial reports, which is indicated by the value of $t$ count $2.689>t$ table 2.021 with a significance value $<0.05$. Based on the results of multiple linear regression analysis, a justification can be 
taken that there is a significant effect of competency on the quality of financial reports. Theoretically, in government regulation No. 8 of 2006, concerning financial reporting and performance of government agencies, it is stated that financial reports are a form of accountability for the management of state and regional finances for one period. The Governmental Accounting Standards Committee (2005) explains that the responsibility for preparing and presenting financial statements lies with the leadership of the entity. Within the scope of regional government, what is meant by the head of the entity is each Regional Work Units head as an accounting entity and each regent as a reporting entity. In the Regional Government structure, Regional Work Units is an accounting entity that has the obligation to record transactions of income, assets and other than cash that occur within the Regional Work Units. Therefore, every part of government must be filled with human resources who have competence in competency and other related financial sciences.

In the government sector, especially to produce quality regional financial reports, human resources who understand and are competent in government accounting, regional finance and even organizational governance are needed. To produce quality financial reports, the quality of employees involved in the preparation of financial statements must understand and understand how the accounting process and implementation is carried out based on applicable regulations. Someone said to understand accounting is to understand and be clever about how the accounting process is carried out until it becomes a financial report based on the principles and standards for preparing financial statements that are applied in Government Regulation Number 71 of 2010 concerning Government Accounting Standards. Based on these concepts, empirically the results of this study are consistent with Diani (2014), which states that accounting understanding has a positive and significant effect on the quality of financial statements.

\section{Effect of Accounting Information Systems Implementation on the Quality of Local Governments Financial Reports}

The results showed that there was a positive and significant effect between the implementation of accounting information systems on the quality of financial reports. The regression equation has a positive coefficient direction. There is a significant effect of the use of regional financial accounting information systems on the quality of financial reports, which is indicated by the value of $t_{\text {count }} 3.897>t$ table 2.021 with a significance number $<$ 0.05 . Based on the results of multiple linear regression analysis, a justification can be taken by considering theoretical and empirical studies. In theory, based on Government Regulation of the Republic of Indonesia Number 56 of 2005 concerning Regional Financial Information Systems, it is stated that a local financial information system is a system that documents, administers, and processes regional financial management data and other related data into information presented to the public and as material. Decision making in the framework of planning, implementing, and reporting the accountability of local governments. The Buleleng Regency Government in preparing financial reports uses a computerized information system called Local Office Accounting Information System.

Through the use of this accounting information system, the Buleleng Regency government can produce quality financial reports. Information technology can be utilized effectively if members in the organization can use the technology properly. Therefore, it is very important for organizational members to understand and predict the usefulness of the system. The use of the information system is intended to be useful and to improve the 
performance of the Buleleng Regency local government. Through improved performance, the government will also produce good results, namely in the form of quality financial reports. Empirically the results of this study are consistent with the results of research conducted by Ratifah \& Ridwan (2012); Anggriawan \& Yudianto (2018), Sagara (2015) namely the use of local financial accounting information systems has a positive and significant effect on the quality of financial reports.

\section{Effect of Work Experience on Quality of Local Governments Financial Reports}

The results showed that work experience had a positive and significant effect on the quality of local governments financial reports. The regression equation has a positive coefficient direction. The positive effect shows that the relationship between work experience and the quality of financial reports is unidirectional. There is a significant effect of work experience on the quality of financial statements, which is indicated by the value of $t$ count $4.309>t_{\text {table }}$ 2.021 with a significance value $<0.05$. Based on the results of multiple linear regression analysis, a justification can be taken that there is a significant effect of work experience on the quality of financial statements. Theoretically, the quality of regional financial reports is reflected in the normative measures listed in Government Regulation No. 71/2010. The normative prerequisites needed for government financial reports to meet the desired quality are comparable and understandable. Comparable is the information contained in the financial statements will be more useful if it can be compared with the financial statements of the previous period or the financial statements of other reporting entities in general. Understandable is the information presented in financial statements that can be understood by users and expressed in forms and terms that are adjusted to the limits of understanding of the users to learn the information in question. To be able to meet the normative prerequisites required for government financial reports to meet good quality, employee work experience is required.

Work experience is a measure of an employee who can put himself in the right conditions, dare to take risks, be able to face challenges with full responsibility and be able to communicate well with various parties, this experience will be a top priority as a promotion consideration because employees will better understand and master a skills in the field he is practicing (Edy, 2009). The longer the work experience, the more experienced an employee is, so it is hoped that the quality of work will be better. The work experience of the finance / accounting department staff will make it easier to do the job because with this professional work experience, the finance / accounting department staff understands better and is dexterous in preparing financial reports. Professional work experience in accounting will provide more accuracy in preparing financial reports. Empirically the results of this study are consistent with the results of research conducted by Charolina \& Abdullah (2013) which shows that work experience has a positive and significant effect on the quality of financial statements.

\section{Effect of Internal Audit Role on the Quality of Financial Statements}

The results showed that the role of internal audit has a positive and significant effect on the quality of financial reports. The regression equation has a positive coefficient direction. There is a significant influence on the role of internal audit on the quality of financial statements, which is indicated by the value of $t_{\text {count }} 2.444>t$ table 2.021 with a significance number $<0.05$. Based on the results of multiple linear regression analysis, a justification can 
be drawn that there is a significant influence on the role of internal audit on the quality of financial statements. Theoretically, in order for a financial report to be of benefit to its users, the financial report must have quality information value and is useful in decision making. The quality of these financial reports is reflected in the normative measures that need to be embodied in accounting information in order to fulfill its objectives. In Government Regulation Number 71 of 2010, one of the normative prerequisites needed so that government financial reports can meet the desired quality is reliable. Reliable financial reports are met if the information in the financial statements is free from misleading understanding and material errors, presents every fact honestly and can be verified.

The role of the internal auditor (the role of the inspectorate) as the government's internal supervisor will be able to assist local governments in preparing quality and reliable government financial reports. To determine the reliability of the financial information produced by the Regional Work Units, the inspectorate reviews its financial reports. The review process of the financial statements determines whether the financial statements have been presented in accordance with applicable regulations. The input provided by the inspectorate in this review process will guide the realization of financial reports in accordance with government accounting standards, thereby improving the quality of regional financial reports. Empirically the results of this study are consistent with the results of the research of Tambingon et al (2018), which states that the role of internal audit has a positive and significant effect on the quality of financial statements. Meanwhile, this research is not consistent with Agustiningsih et al (2017) which states that audit findings have no effect on the level of disclosure in local government financial reports.

\section{CONCLUSION}

There is a positive and significant influence between competency, implementation of accounting information system, work experience, and the role of internal audit on the quality of local governments financial reports. The results of this study can explain the effect of independent variables on financial statements. Existing theories on organizational financial management strengthen the relationship between competency, implementation of accounting information systems, work experience, and the role of internal audit on the quality of financial reports. The results of empirical evidence from this study can be used to solve problems that occur in the quality of accounting information systems and the quality of financial reports. The quality of accounting information system financial reports can be improved through improving the accounting information system, tool commitment and the role of internal audit.

\section{Suggestion}

Local governments should conduct ongoing evaluations of competency, implementation of regional financial accounting information system, work experience, and the role of internal audit on the quality of financial reports. In addition, there is a need for periodic training for all staff who handle finances so that later government financial management will be better in order to achieve quality financial reports. Further researchers are advised to expand the research population, namely by increasing the number of officers working at the Regional Government Agency Offices not only in the Buleleng area, so that research results are 
obtained with a higher level of generalization. In subsequent studies, we can add other variables that affect the quality of financial reports, such as work motivation and training intensity.

\section{REFERENCES}

Agustiningsih, S. W., Murni, S., \& Putri, G. A. (2017). Audit Findings, Local Government Characteristics, and Local Government Financial Statement Disclosure. Review of Integrative Business and Economics Research, 6(3), 179-187. Retrieved from http://buscompress.com/uploads/3/4/9/8/34980536/riber_6-3_a17-121_179-187.pdf

Anggriawan, F. T., \& Yudianto, I. (2018). Factors Affecting Information Quality of Local Government Financial Statement. Journal of Accounting Auditing and Business, 1(1), 3042. Retrieved from http://jurnal.unpad.ac.id/jaab

Astuti, M. T. (2008). Pengaruh Penerapan Sistem Informasi Akuntansi Terhadap Kinerja Individu (Penelitian Pada SKPD di Lingkungan Pemerintah Kota Malang). Universitas Brawijaya.

Charolina, O., \& Abdullah, H. (2013). Pengaruh Implementasi Pengelolaan Keuangan Dan Pengalaman Kerja Terhadap Kualitas Laporan Keuangan Komisi Pemilihan Umum. Jurnal Fainess, 3(3), 82-94.

Diani, D. I. (2014). Pengaruh Pemahaman Akuntansi, Pemanfaatan Sistem Informasi Akuntansi Keuangan Daerah dan Peran Internal Audit Terhadap Kualitas Laporan Keuangan Pemerintah Daerah (Studi Empiris pada Satuan Kerja Perangkat Daerah di Kota Pariaman). Artikel Ilmiah Mahasiwa, 1-23.

Edy, S. (2009). Manajemen Sumber Daya Manusia (pertama, c). Jakarta: Kencana.

Fitriana, \& Wahyudin, A. (2017). Factors Influencing The Quality of Financial Reporting on Local Government of Purbalingga. Accounting Analysis Journal, 6(1), 27-38. Retrieved from https://journal.unnes.ac.id/sju/index.php/aaj/article/view/18597/9966

Ghozali, I. (2011). Aplikasi Analisis Multivariate Dengan Program IBM SPSS 19 (5th ed.). Semarang: Badan Penerbitan Universitas Diponegoro.

Huang, C.-Y., Shen, Y.-C., Chiang, I.-P., \& Lin, C.-S. (2007). Concentration of Web users' Online Information Behaviour. Information Research, 12(4), Paper 324. Retrieved from http://informationr.net/ir/12-4/paper324.html

Muda, I., Harahap, A. H., Erlina, Ginting, S., Maksum, A., \& Abubakar, E. (2018). Factors of quality of financial report of local government in Indonesia. In IOP Conf. Series: Earth and Environmental Science (pp. 1-6). IOP Publishing Ltd.

Praditasari, P., \& Asrori. (2018). The Factors That Affect Fraudulent Financial Statements of the Local Government. Accounting Analysis Journal, 7(2), 79-86. Retrieved from https://journal.unnes.ac.id/sju/index.php/aaj/article/view/21181/12952

Ratifah, If., \& Ridwan, M. (2012). Komitmen Organisasi Memoderasi Pengaruh Sistem Akuntansi Keuangan Daerah terhadap Kualitas Laporan Keuangan. Trikonomika, 11(1), 29-39. Retrieved from http://digilib.mercubuana.ac.id/manager/t!@file_artikel_abstrak/Isi_Artikel_78472808654 2.pdf

Sagara, Y. (2015). The Effect of Implementation Accounting Information System and Competence of Human Resources on the Quality of Financial Reporting. Research Journal of Finance and Accounting, 6(10), 111-115. 
Sari, L. N. (2014). Pengaruh Kapasitas Sumber Daya Manusia Dan Peran Auditor Internal Pemerintah Terhadap Kualitas Laporan Keuangan Pemerintah Daerah (Studi Empiris pada Satuan Kerja Perangkat Daerah Kabupaten Kerinci). Jurnal Akuntansi, 2(2), 1-20. Retrieved from http://ejournal.unp.ac.id/students/index.php/akt/article/view/1060/754

Sugiyono. (2014). Metode Penelitian Kuantitatif Kualitatif Dan R\&D. Bandung: Alfabeta.

Suwardjono. (2011). Teori Akuntansi perekayasaan Pelaporan Keuangan (Edisi Keti). Yogyakarta: BPFE.

Tambingon, H. N., Yadiati, W., \& Kewo, C. L. (2018). Determinant Factors Influencing the Quality of Financial Reporting Local Government in Indonesia. International Journal of Economics and Financial Issues, 8(2), 262-268. Retrieved from https://www.econjournals.com/index.php/ijefi/article/view/6160/pdf

Yuliani, S., Nadirsyah, N., \& Bakar, U. (2010). Pengaruh Pemahaman Akuntansi, Pemanfaatan Sistem Informasi Akuntansi Keuangan Daerah dan Peran Internal Audit Terhadap Kualitas Laporan Keuangan Pemerintah Daerah (Studi Pada Pemerintah Kota Banda Aceh). Journal of Accounting Research and Review, 3(2), 206-220. Retrieved from http://jurnal.unsyiah.ac.id/TRA/article/view/340/325

Zainullah, Amin, Suharyanto, A., \& Budio, S. (2012). Pengaruh Upah, Kemampuan dan Pengalaman Kerja Terhadap Kinerja Pekerja Pelaksanaan Bekisting pada Pekerjaan Beton. Jurnal Rekayasa Sipil, 6(2), 125-129. 